\title{
Happiness as a factor of the national security of Russia
}

\author{
Anatoly Anatoljevich Lukutin ${ }^{1 *}$, Nikolay Nikolayevich Ustyuzhanin ${ }^{2}$, and Dmitry \\ Vladimirovich Semenov ${ }^{1}$ \\ ${ }^{1}$ Linguistics University of Nizhny Novgorod, Chair of Physical Culture and Sport, Nizhny Novgorod, \\ Russia \\ ${ }^{2}$ The Ministry of Internal Affairs of the Russian Federation, Chair of Fire Training, Nizhny \\ Novgorod, Russia
}

\begin{abstract}
Based on the conducted research, the article proposes and substantiates an innovative thesis about the possibility and need to consider and utilize the phenomenon of happiness as an independent factor of strengthening the national security of modern Russia. Such an interpretation is based on the analysis of the influence of other (positive and negative) factors on its development, consideration of the theoretical foundations of the institution of national security and its priorities, and the results of foreign and Russian research on security and happiness indicating not only the contradictions between them but also the deep reasons that unite them in nature. In practice, improving the quality of security in all areas is associated with the mandatory transition of activities ensuring it to the controlled positive development of the entire system and each of its elements and the creation of conditions for the satisfaction of the human need for happiness in any threatening conditions of the internal and external life. Such a perspective is considered in the context of the relevance and peculiarities of the felicitous approach to understanding and achieving the strategic role, goals, and applied objectives of the Russian state in the form of higher education. Meanwhile, education itself is viewed not only as an instrument of state policy but also as an effective area for its modernization synchronized with the demand for human development as a measure of true happiness and the security of society and the state. In this context, special attention is given to students as the subjects and objects of the problems of meeting the need for happiness and security. The article discloses the features of the existing and promising pedagogical conditions and models for the implementation of the felicitous approach allowing graduates to become potential carriers of harmonization of activities of a citizen, society, and state institutions in the interests of national security.
\end{abstract}

Keywords: happiness, national security, education, students.

\footnotetext{
*Corresponding author: lukutin66@mail.ru
} 


\section{Introduction}

Analysis of a wide range of Russian and foreign research on social security of people shows that it is contingent on numerous conditions and factors and is relevant as a scientific problem to the same degree as the issues of ensuring the security of humanity and the forms of its existence [1:8-12]. We argue that since the very emergence of humanity and throughout the subsequent millennia, the interaction of these problems and the possibility of solving them has been associated with the effect of epistemological unity and incompatibility of these objects of scientific knowledge. The most recent examples are the events related to the coronavirus pandemic and its global crisis consequences, the pre-election situation in the United States, and the military conflict between Azerbaijan and Armenia.

Researchers directly or indirectly recognize the unique and, at first glance, paradoxical role that historically belongs to modern Russia, its special place in the global influence on the past, present, and future security of individuals and the world community [2]. In particular, among the positive factors specialists recognize the thousand-year history of Russian statehood; its relatively positive experience in the practical implementation of models of optimal social cooperation between individuals, society, and the state; significant humanistic, positive inter-ethnic, multi-confessional, scientific and technological, natural resource, intellectual and creative, military-historical, mobilization, and military-strategic potential, etc. [3]. The negative factors include the factors of historical memory about the violation of rights and freedoms during the years of mass repression, persecution for dissent, the monopoly of communist ideology and the CPSU in political and public life, voluntarism in the economy of the Soviet period; radical collapse of customary values, etc. In our view, the aforementioned factors demonstrate the increasing relevance of shifting the attention of the scientific community, as well as of the very subjects of these problems, to the additional horizons and "verticals" of knowledge and activity in the search for interaction in the sphere of ensuring the social security of Russia. The concept of "national security" was introduced and theoretically developed in Russia fairly recently (in 1997). According to the regulatory legal documents, its structure implies the unity of security of individuals, society, and the state. The main priority within it is given to the security of a person and a citizen [3]. Research and the indicated legal documents identify not only the content of national interests of the state and the main directions of activity of an individual, society, and the state as the conditions for following this priority but also the requirements for the methodology and priority methods of further scientific support for the demand to improve national security as a system [4].

\section{Discussion}

In association with the aforementioned, we draw attention to a relatively new trend in the human sciences that emerged in the 20th and especially in the 21 st century. Due to this trend, the guidelines and emphases in the scientific knowledge of the indicated problems have been supplemented by a new paradigm of their theoretical vision, a different social and applied (in particular, educational and pedagogical) context, have acquired an integral, interdisciplinary vector of research and recommendations. The reason for this (which, in particular, is demonstrated by the speeches of our international conference participants) was the study of the phenomenon of happiness as a factor of human life, well-being, destiny strategy, and, in particular, national security.

The results of foreign and Russian studies show that the decisive role in a person's positive or negative evaluation of their security, life, and even themselves is played by the context of positive or negative (often subjective and irrational) experiences of moments or longer periods of happiness [5: 4-6]. 
Scientific works, articles, and textbooks in various spheres of knowledge present a wide variety of directions and unique author's approaches to the definition of the essence and characteristics of happiness [6]. However, the current federal and departmental normative legal documents that constitute the issues of legal rights and interests of a person and a citizen and the national interests and national security of the Russian Federation still lack the definition of "happiness", as well as the related and derivative concepts widely used in the indicated studies ("right to happiness", "economics, politics, pedagogy of happiness", "the felicitous factor of its security") [7: 15]. N.N. Rybalkin states that "... security in itself presents the correspondence of something to its own objective nature stemming from the limited substance" [8: 17]. In a different work, Rybalkin notes that "the most dangerous threat to a thing is the danger to its essence, its idea (emphasis added)" [8: 26]. The author suggests that with this interpretation of the metaphysical side of security, it is expedient to consider the state of the nation's spiritual and moral essence. A nation that cannot be itself in reality will never be truly happy. Therefore, a vital modern objective of the state should be enshrining the felicitous interpretation of national security in its legal system [9: 14]. $\Phi$ unanimous position is expressed by O.V. Parilov: modern Russia is experiencing a total deideologization as a vacuum of ideas capable of uniting the nation on the one hand and a complete break from the spiritual roots of the nation, its moral traditions on the other [10: 286]. Under such circumstances, it is essential to return to the intangible beginnings, the ultimate foundations of our collective soul, to restore the lost continuity with the creative and just Source. Referring to global studies, A.D. Ursul argues that a significant improvement in the quality of security in all spheres can only be achieved through the transition (emphasis added) of its activities to the controlled positive development of the entire system and each of its elements [11].

The starting point for understanding the underlying causes of the relationship between security and happiness is ultimately the ability (competence) of a researcher and practitioner to see the true nature of security and provide it through the lens of the human need for happiness under any threatening conditions of internal and external life. The conclusions of Russian scientists, same as popular wisdom, suggest that the value of the development and self-development of every Russian (regardless of whether they are an ordinary citizen, a banker, or leader of the state) lies in not only their right and duty but also the ability to be truly happy. Said ability is assessed through the level and success in confronting the threats to the security of the very idea (dream) of happiness and ideally encompasses everything a person can love except for themselves and what gives them extremely positive feelings (affects) that cannot be mistaken for anything else. Among the many conditions of happiness (living with loved ones in one's own home, spiritual and material well-being, travel opportunities, etc.), researchers indicate the satisfaction of the need and the personal ability to partake in providing the security and well-being (spiritual and physical) of individuals, communities, nations, and the entire multi-national country as the most realistic foundation for improving the internal stability of modern Russia and the national goal adopted by the Russian population [12].

The next scope of the studied scientific works on the examined problems touches upon the system of general and higher education overall as an instrument for ensuring national security in all three components. Pedagogical science is currently striving to allocate and formulate the fundamental foundations for the modern model of education. In this regard, the relevance of understanding the philosophical and worldview basis of pedagogy and its felicitous components in the modern system of higher education in general will continue to increase [13]. Researchers largely associate this with the negative manifestations of the "shadow" side of educational and life activities of school and university students, their controllability by extremist views and protest activity, and the mass spread of new pseudoreligious cults [14: 26-33]. Nevertheless, since many studies note the dynamics of the 
processes of support and development of the modern higher education system of Russia, the scientific world and the social institutions in solidarity with it view it not only as an instrument of state policy but also as an effective environment for the modernization of state policy in accordance with the demands for human development as a measure of happiness [15: 18-27].

As a result, the structure and content of the pedagogical conditions and the principle model that should be based on the scientifically derived patterns, laws, technologies, methods, techniques, and practices for "working with happiness" in varied conditions with certain categories of students have become clear [16].

\section{Conclusion}

Summarizing the preliminary results of the theoretical study of the stated topic presented above, let us formulate some basic conclusions. Ontologically, as a complex subject-subjectobject formation, happiness serves as a human reference point in the search, verification, and acquisition of the meaning of life. From the point of scientific knowledge, both happiness and security are interdisciplinary categories that have numerous multifactorial, multilevel, multivalued, complex (subjective and objective), direct and mediated connections and contradictions between each other, as well as between the essence (idea) of these objects of research. A profound condition for smoothing the contradictions and improving the positive mutual interaction within the system of national security of Russia is the consistency of the mutually beneficial orientation, quality of processes, and results of the felicitation-centered development of each of its subjects.

Within these processes, education and studenthood occupy a position that strongly determines the present and future of national security. The current state of the Russian education system allows it to be open to change since, based on substantial evidence, the scientific world and social institutions in solidarity with it view it not only as an instrument of state policy but also as an effective environment for its modernization that is synchronous with the demands for human development as a measure of true happiness. The higher education system needs to implement the felicitous potential found in the safe and healthy lifestyle regarding oneself and one's loved ones, forming a happy environment, in the learning and social activities of students and teachers associated with cooperation aimed at caring for others. This work should be based on specialized pedagogical conditions and models of the educational process.

Given the current international situation and the internal state, the cumulative spiritual and historical immunity, and geopolitical potential of Russia, it is evident that the relevance of recognizing and utilizing the felicitous perspective including the educational content of the harmonization of relations between the individual, society, and the state in the interests of common security, should and will increase.

\section{References}

1. V.E. Makarov, Upravlenie obespecheniem natsionalnoi bezopasnosti v sotsialnoi sfere Rossii: politologicheskii analiz [Management of national security in the social sphere of Russia: a political analysis]. Summary of a doctoral dissertation in philosophy (Russian State Social University, Moscow, 2011)

2. Issledovanie natsionalnoi bezopasnosti Rossii [Research on Russia's national security]. Fundamentalnaia elektronnaia baza uchebnykh materialov [Fundamental electronic database of educational materials] (n.d.). Accessed on: January 10, 2021. [Online]. 
Available: https://works.doklad.ru/view/zjN7QJRjf60/all.html (Accessed January 10, 2021).

3. Kontseptsiia natsionalnoi bezopasnosti Rossiiskoi Federatsii [The National Security Concept of the Russian Federation]. Accessed on: January 09, 2021. [Online]. Available: http://www.scrf.gov.ru/documents/77.html

4. O Strategii natsionalnoi bezopasnosti Rossiiskoi Federatsii: Ukaz Prezidenta RF ot 31.12.2015 № 683 [On the National Security Strategy of the Russian Federation: Presidential Decree No. 683 of December 31, 2015]. Accessed on: January 07, 2021. [Online]. Available: http://www.scrf.gov.ru/documents/99.html

5. M.N. Koroleva, Schaste kak sotsiokulturnyi fenomen (sotsiologicheskii analiz) [Happiness as a socio-cultural phenomenon (sociological analysis)]. Summary of a doctoral dissertation in philosophy (Russian State University for the Humanities, Moscow, 2013)

6. N.N. Rybalkin, Filosofiia bezopasnosti [Philosophy of security] (Moscow PsychologySocial Institute, Moscow, 2006)

7. V.A. Lisenko, Kontsept schaste i ego metaforicheskoe prelomlenie [The concept of happiness and its metaphorical interpretation] (Ural Federal University named after the first President of Russia B. N. Yeltsin, Ekaterinburg, 2016). Accessed on: January 06, 2021. [Online]. Available:

https://elar.urfu.ru/bitstream/10995/42976/1/m_th_m.a.lysenko_2016.pdf

8. N.N. Rybalkin, Priroda bezopasnosti [The nature of security]: summary of a doctoral dissertation in philosophy (Moscow, 2003)

9. T.S. Paniotova, Schastlivoe obshchestvo kak utopicheskii konstitutiv [The happy society as a utopian constitutive], in Proceedings of the International Scientific Conference "Fundamental Studies of the Happiness Phenomenon", December 16-19, (Linguistic University of Nizhny Novgorod, Nizhny Novgorod, 2020)

10. O.V.Parilov, Statia 13 Konstitutsii RF i formirovanie gosudarstvennoi ideologii [Article 13 of the Russian Constitution and the formation of state ideology], in Materials of the round table on World Philosophy Day on the topic "Law and Power". Bulletin of the Nizhny Novgorod Academy of the Ministry of Internal Affairs of Russia, 1(45) (2019)

11. A.D. Ursul, Voprosy Bezopasnosti [Security Questions], 3, 62-87 (2017)

12. E.O. Kubiakin, Vlast [Authority], 9 (2010)

13. M.V. Lapukhina Analitika sushchnosti schastia v russkoi traditsionnoi kulture [Analysis of the essence of happiness in traditional Russian culture]: summary of a Ph.D. dissertation in philosophy (Tambov State University named after G. R. Derzhavin, Tambov, 2006). Accessed on: December 20, 2020. [Online]. Available: http://www.dissercat.com/content/analitika-sushchnostischastya-v-russkoitraditsionnoi-kulture\#ixzz2VQuy70Tg

14. Iu.A. Anoshko, Podvodnye kamni New Age: vzgliad khristianskogo bogoslova [Pitfalls of the New Age: the view of a Christian theologian], in Humanitarian knowledge and spiritual security: Proceedings of the 3rd International Scientific-Practical Conference, 26 - 33, Grozny, December 1-3, 2016 (Chechen State Pedagogical University, ALEF (IE Ovchinnikov M.A.), Makhachkala, 2016)

15. L.G. Abramova, Aktualnye Problemy Sotsialno-Gumanitarnykh Nauk [Actual Problems of Social and Human Sciences], 18-27 (Baltic Federal University Publishing House, Kaliningrad, 2003) 
16. N.V. Kachur, Felitsitarnost sovremennoi molodezhi: sotsiologicheskii rakurs izmereniia [Felicitativeness of modern youth: sociological perspective on measurement]. Ph.D. dissertation in sociology (Saratov State University, Saratov, 2014) 